\title{
Parametrising arbitrary constructions
}

\section{Introduction}

This article deals with the cross-linguistic distribution of the arbitrary si/se (henceforth $s_{\text {arb }}$ ) in Romance. ${ }^{1} S_{\text {arb }}$ constructions are sentences featuring an implicit argument with an arbitrary interpretation, i.e. an argument denoting a set of individuals that possibly contains the speaker. ${ }^{2}$ The null argument usually corresponds to the external argument (EA) of transitive and unergative verbs and, to a lesser extent, the internal argument (IA) of unaccusatives.

According to descriptive grammars and previous studies (but there is no consensus on the terminology, see fn. 3), $s_{\text {arb }}$ constructions come in three types:

i. the impersonal construction stricto sensu, with intransitive verbs or transitives with an accusative complement, cf. (1). The finite verb is always third person singular, while the past participle of unaccusative verbs exhibits plural inflection, cf. (1)a.

ii. the so-called passive-like construction ${ }^{3}$, in which an (active) transitive verb agrees with the IA, cf. (2)a. The IA must be third person (D'Alessandro 2007; cf. section 4.1); some speakers allow a non-agreeing variant - see $(2) \mathrm{b}$ - in which the verb shows no plural agreement ${ }^{4}$.

iii. the middle construction, in which a transitive verb without specific time reference agrees with the IA, cf. (3). Middles differ from passive-like constructions as the former have a property reading, whereas the latter have an event reading; Middles will not be addressed in the present study.
a. Si è partiti presto
$s=$ is left.PL early
'We left early'
b. Si dorme
$s=$ sleeps
'one sleeps'

\footnotetext{
${ }^{1}$ Acknowledgments.

${ }^{2}$ Cinque 1988 distinguishes a quasi-universal reading ('people') from a quasi-existential reading that is "roughly paraphrasable as 'unspecified set of people including the speaker' ('we')" (Cinque 1988, 542). The latter is normally preferred with unaccusative verbs. Although the quasi-universal reading of $s_{\text {arb }}$ is close, in certain context, to the reading of a first person plural referential subject, it cannot be reduced entirely to a referential subject. In fact, it is always possible to build a context in which the speaker is excluded, e.g. quando si partiva per la prima guerra mondiale, lit. 'when $s_{\text {arb }}$ leaves for the first world war'. Hence, I often translate $s_{\text {arb }}$ as 'we' in all the examples with unaccusatives, although I never use we or other English forms in the glosses because no English form corresponds exactly to the notions of quasi-universal or quasi-existential arbitrary subject.

As for the interpretation of impersonal constructions in dialects, no significant deviation from the semantics of standard Italian has been reported in the literature on dialects. I have checked native speakers of the dialects exemplified in the article, and they could not find any relevant mismatch between the interpretation of Italian and dialect sentences.

${ }^{3}$ Some scholars - Cennamo 1993, 1995, 1997; Parry 1998 among others - use the term passive to refer to $s_{\text {arb }}$ constructions having the subject in preverbal position. However, as Raposo \& Uriagereka 1996 pointed out, the subject of passive-like constructions is arguably in A' position (see also Pescarini forth.). On terminological issues, see also D'Alessandro 2007: 39.

4 According to D'Alessandro 2007: 55ff, the agreeing variant denotes accomplishment predicates, while the nonagreeing variant denotes activity predicates. In what follows I will concentrate on the former, disregarding the latter, which is accepted by a subset of speakers. It is worth noting that lack of number agreement with third person postverbal subjects is found in several areas of Italy (e.g. central Italy, Tuscany; see Brandi and Cordin 1989, Saccon 1993, Cardinaletti 1997; for an overview, see D’Alessandro \& Pescarini 2016). In these areas, the default 3sg agreement of $s_{\text {arb }}$ constructions is no exception, as it arguably follows from orthogonal syntactic properties.
} 
c. Losi mangia

$\mathrm{it}=s=$ eats

'one eats it'

(2)

a. Questa sera si leggono due libri.

(passive-like)

This evening $s=$ read two books

'This evening we will read two books'

b. ${ }^{\%}$ Questa sera si legge due libri.

This evening $s=$ reads two books

'This evening we will read two books'

(3) Quel libro si legge facilmente.

(middle)

That book $s=$ reads easily

'That book is easy to read'

$S_{\text {arb }}$ constructions are arguably related to other se/si constructions, e.g. anticausative, reflexive, reciprocal, etc., as all involve some pattern of valence reduction (Comrie 1985; Bentley 2006; in the generative framework: Kayne 1986, Manzini 1986). However, whether a single formal mechanism can account for the multifaceted behaviour of si/se across the Romance languages is still an open question. I therefore confine the following discussion to constructions in which si/se gives rise to an arbitrary interpretation, leaving the others to future research.

Building on previous accounts (in particular, Cinque 1988 and Roberts 2010), this article aims to reconsider some restrictions on the distribution of $s_{\text {arb }}$. The main theoretical tenet of the work is that the observed cross-linguistic variation results from a set of micro-parameters ruling the merging site of $s_{\text {arb }}$ and the agree relations occurring between $s_{\text {arb }}$ and probing elements such as $\mathrm{v}$ and $\mathrm{T}$ (Roberts 2010). In particular, I argue that the distribution of $s_{\text {arb }}$ can be accounted for by refining the analysis put forth by Roberts 2010. On the basis of data from north-western Italian dialects (Parry 1998), the proposed model aims to account for languages allowing $s_{\text {arb }}$ to occur with unaccusative verbs, but not with passive, copular constructions, and with accusative clitics.

The present article supports the so-called microparametric approach to the study of linguistic variation. As Kayne 1996: xiii pointed out, "the technique of examining a large number of very closely related languages promises to provide a broad understanding of parameters at their finestgrained (microparameters)." Departing slightly from Kayne's approach, I assume that microparametric settings are clustered and that "aggregate settings are favoured by markedness considerations" (Roberts \& Holmberg 2010: 39). In particular, the following analysis builds on a constraint-based model of markedness in the spirit of Calabrese 1995, 2005.

The structure of the article is as follows: section 2 introduces some typological divisions among the Romance languages regarding the distribution of $s_{\text {arb }}$ in unaccusative sentences; section 3 discusses previous accounts of the aforementioned restrictions (Cinque 1988; Dobrovie Sorin 1998, 2006; Roberts 2010); section 4 deals with the co-occurrence of $s_{\text {arb }}$ and object clitics; section 5 focuses on the syntax of $s_{\text {arb }}$ in passive and predicative constructions.

\section{Unaccusatives}

In several Romance languages, $s_{\text {arb }}$ cannot occur in (certain) unaccusative environments or with accusative clitics. As summarised in table (4), old Italian - namely, $13^{\text {th }}$ century Florentine - does not show attestations of $s_{\text {arb }}$ occuring in passive and copular constructions, while the occurrence with unaccusative verbs is rather rare and, according to Salvi $2008 \mathrm{a} / \mathrm{b}$, is unattested in the earliest documents; Romanian and northwestern Italian dialects (NWIDs) allow $s_{\text {arb }}$ to occur with unaccusative verbs, but not in passive and copular constructions and with accusative clitics 
(Dobrovie-Sorin 1998; Parry 1998), although first and second person object clitics combine with $s_{\text {arb }}$ more readily than third person clitics (Mendikoetxea \& Battye 1990 on Genovese (Ligurian)); Italian and Spanish exhibit no restriction on unaccusatives, passives, predicative constructions in untensed environments, but Spanish differs from Italian as the impersonal $s_{\text {arb }}$ cannot co-occur freely with all kinds of object clitics (Mendikoetxea 2008; Ordoñez and Treviño 2016). In the following subsections I report the data illustrating the restrictions introduced so far.

\begin{tabular}{|l|c|c|c|c|}
\cline { 2 - 5 } \multicolumn{1}{c|}{} & old It. & Ro., NWIDs & Sp. & It. \\
\hline Unaccusative verbs & $\mathbf{x}$ & $\checkmark$ & $\checkmark$ & $\checkmark$ \\
\hline Passive and copular constructions & $\mathbf{x}$ & $\mathbf{x}$ & $\checkmark$ & $\checkmark$ \\
\hline Co-occurrence with 3p clitics & $\mathbf{x}$ & $\mathbf{x}$ & $\%$ & $\checkmark$ \\
\hline
\end{tabular}

Occurrence of $s_{\text {arb }}$ in old Italian, Romanian, North Western Italian dialects, Spanish, and Italian in tensed clauses

\subsection{Old Italian}

Old Italian - namely, $13^{\text {th }}$ century Florentine - does not show attestations of $s_{\text {arb }}$ occurring in passive and copular constructions, while the occurrence with unaccusative verbs is rather rare (Salvi 2008a/b, 2010: 151-160). Many occurrences of $s_{\text {arb }}$ with unacusative verbs (in particular with verbs of motion) are in fact instances of $s$-unaccusative verbs akin to those found in modern Spanish (Cuervo 2014). Crucially, $s$-anticausatives differ from impersonal unaccusatives in having a DP argument, which, if dropped, receives a referential reading, e.g. se murió 'he/she died'. By contrast,

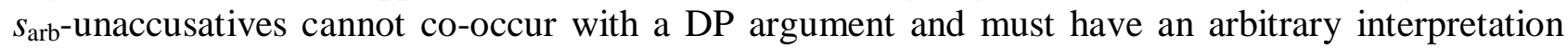
meaning 'one, the people, we'. As previously said, the latter is absent in the earliest attestations of Italian as, according to Salvi $2008 \mathrm{a} / \mathrm{b}$, the first attestations of fully-fledged $s_{\text {arb }}$ constructions with unaccusative verbs are found in Dante's writings, see (5). As previously mentioned, in the same chronological stage the impersonal si cannot co-occur with accusative clitics.

(5) a. Io tenni li piedi in quella parte de la vita di là da la quale I kept the feet in that part of the life from there from the whom non si puote ire più per intendimento di ritonare (Dante. VN 14.8) not $s=$ can go anymore for intention of returning

'I have set foot in that region of life where it is not possible to go with any more intention of returning'

b. ... non vuol che 'n sua città per me si vegna (Dante, Inf. 1 v. 126) not want that in his city through me $s=$ come.SUBJ

'He will not let anyone be led to his city by me'

\subsection{Romanian}

In Romanian, $s_{\text {arb }}$ is not allowed in passive or copular sentences - cf. (6) and (7) respectively - and in combination with accusative clitics, see (8) (data from Dobrovie-Sorin 1998). The following couples of examples illustrate the contrast between Romanian and modern Italian, which does not exhibit any restriction in finite clauses:
a. Spesso
si è traditi
dai falsi amici
(Italian)
b.*Adesea se este trădat
de prieteni falşi
(Romanian)
Frequently $s=$ is betrayed by friends false
'One is frequently betrayed by false friends'

a. Non si è mai soddisfatti

(Italian) 
b. ${ }^{*} \mathrm{Nu} \quad$ se este niciodată mulţumit.

(Romanian)

Not $s=$ is never satisfied

'One is never satisfied.'

(8) a. (Le materie umanistiche) le

b. *(Stiinţele umane) le

si studia in questa università (Italian)

(the humanities)

them $=s=$ studies in this university

'You can study the humanities in this university'

As for unaccusatives, it is worth noting that verbs such as arrive, die, etc. are free to occur with $s_{\text {arb}}$, see (9). However, the unaccusative status of those verbs is far from straightforward as the customary unaccusativity tests do not apply.
a. Ieri
s-a
ajuns la timp
Yesterday $\mathrm{s}=$ has arrived in time
'Yesterday people arrived on time.'
b. La noi, se moare des din cauza cancerului
In us $\mathrm{s}=$ dies often because.of cancer
'In our country people often die because of cancer'

\subsection{Piedmontese and Ligurian dialects}

Parry $(1995 ; 1998)$ notes that NWIDs such as Piedmontese and Ligurian exhibit a pattern akin to the one of Romanian: $s_{\text {arb }}$ cannot occur in passive or copular sentences. Examples like (10) are in fact "judged to be calques on Italian usage" (Parry 1998: 91). Notice that (10) contains two instances of as: the former occurs in a copular construction, the latter in a passive one ${ }^{5}$.

(10) *quand ch' as ven vej, as ven dësmentià dai giovo (Pied., Parry 1998: 91) When that $s=$ comes old, $s=$ comes forgotten by.the young 'when one becomes old, one is forgotten by the young'

By contrast, $s_{\text {arb }}$ to occur with unaccusative verbs, see (11) and cf. Parry 1998, 2005. Differently from Romanian, NWIDs allow us to ascertain the unaccusative status of such verbs by means of the usual tests of unaccusativity (ne cliticization, auxiliary selection, participial constructions, etc.; see Burzio 1986).

(11) As sa andova as nas, as sa nen andova as meuir (Pied., Parry 1998: 90) $s=$ knows where $s=$ be.born $s=$ knows not where $s=$ die

'One knows where one was born, but not where one will die'

Moreover, NWIDs, like Romanian, do not allow $s_{\text {arb }}$ to combine with accusative clitics, see (12), while dative, locative and partitive clitics are free to co-occur with $s_{\text {arb }}$, see (13)

(12) $\mathrm{U} \quad(* \mathrm{lu}) \mathrm{s}$ mångia adman

(Monregalese, Pied.)

$\mathrm{SCL}=\mathrm{it}=s=$ eats tomorrow

'We will eat it tomorrow'
a. a $s$ jë
disìa
$\mathrm{SCL}=\mathrm{s}=$ to.him/her/them $=$ say.impf

(Pied., Parry 1998: 87)

\footnotetext{
${ }^{5}$ On the syntax and semantics of venire 'to come' as passive auxiliary, see Sansò and Giacalone Ramat 2016.
} 
'One used to say to them'
b. a $\mathrm{s}$ në contratavo
$\mathrm{SCL}=\mathrm{s}=$ of.them exchanged.hands each year four thousand kilos
'Each year four thousand kilos of them exchanges hands'

In fact, Mendikoetxea \& Battye 1990 point out that in Genovese (Ligurian), first or second person accusative clitics are allowed even in languages banning combinations of $s_{\text {arb }}$ and third person accusative clitics:
a. Finalmente me/te se vedde
At last me/you $=s=$ sees
'At last, one sees me'
b. $*$ I
them $=s=$ reads
'one reads them'

(Genovese)

\subsection{Modern Italian}

In modern Italian, the ban on $s_{\text {arb }}$ with unaccusative verbs only holds true of non-finite tenses, see (15) (Cinque 1988). It is worth recalling that the occurrence of $s_{\text {arb }}$ is allowed only in those untensed environments licensing a nominative subject such as the aux-to-comp constructions below. In the same context, $s_{\text {arb }}$ cannot co-occur with an accusative clitic, as shown in (16)c:

a. Essendosi mangiato male, siamo ripartiti subito.

(Italian: transitive) Being $=s$ eaten badly, we.are left immediately. 'As we had eaten badly, we left immediately'

b. Essendosi dormito male, siamo ripartiti subito. Being $=s$ slept badly, we.are left immediately.

'As we had slept badly, we left immediately'

c. ${ }^{*}$ Essendo-si arrivati tardi, siamo ripartiti subito.

(Italian: unaccusative)

Being $=s$ arrived late, we.are left immediately.

'As we had arrived late, we left immediately'

(16) a. Avendo=la mangiata tutta, sono uscito a comprare ancora pasta. Having=it.F eaten all, I.have gone.out to buy again pasta. 'As I had eaten all of it, I went out to buy more pasta'

b. Essendo=si mangiata tutta la torta, sono uscito a comprare ancora pasta. Being $=s$ eaten all the cake, ...

'As we/one had eaten all the cake, I went out to buy more pasta'

c. Essendo-la-si mangiata tutta, sono uscito a comprare ancora pasta.

Being=it.F $=s$ eaten all , ...

'As we/one have eaten all of it, I went out to buy more pasta'

For the sake of clarity, I repeat below the table summarising the restrictions in tensed clauses introduced in the preceding subsections: 
(17)

\begin{tabular}{|l|c|c|c|c|}
\cline { 2 - 5 } \multicolumn{1}{c|}{} & old It. & Ro., NWIDs & Sp. & It. \\
\hline Unaccusative verbs & $\mathbf{x}$ & $\checkmark$ & $\checkmark$ & $\checkmark$ \\
\hline Passive and copular constructions & $\mathbf{x}$ & $\mathbf{x}$ & $\checkmark$ & $\checkmark$ \\
\hline Co-occurrence with 3p clitics & $\mathbf{x}$ & $\mathbf{x}$ & $\%$ & $\checkmark$ \\
\hline
\end{tabular}

Occurrence of $s_{\text {arb }}$ in old Italian, Romanian, North Western Italian dialects, Spanish, and Italian in tensed clauses

\section{Previous analyses}

Dobrovie-Sorin 1998, 2006 and Salvi 2008a/b argue that Romanian-type languages allow only middle and passive-like $s_{\text {arb }}$ constructions, but no impersonal construction stricto sensu (cf. section 1). According to Dobrovie-Sorin's analysis, middle and passive-like constructions involve ACCUSATIVE $s_{\text {arb }}$, while the latter requires NOMINATIVE $s_{\text {arb }}$. Hence, languages like Italian have both, Romanian lacks NOMINATIVE $s_{\text {arb }}$.

Under the above analysis, the grammaticality of $s_{\text {arb }}$ with unergative verbs is accounted for by assuming that unergatives are a particular kind of transitive verbs with a null cognate object.

As for verbs such as arrive/leave/die (which in Romanian can occur with $s_{\text {arb }}$ ), Dobrovie-Sorin claims that their status is controversial. Since Romanian does not display any clear diagnostic to distinguish unaccusative from unergative verbs, she concludes that in Romanian the unergative/unaccusative divide is "not grammatically encoded" (2006: 140).

In what follows I argue that Dobrovie-Sorin's analysis must be discarded in the light of data from NWIDs - see section 2.3 - in which $s_{\text {arb }}$ can co-occur with unaccusative verbs whose unaccusative status can be confirmed by means of the usual tests (auxiliary selection, ne cliticization, etc.). Since in these languages the unergative/unaccusative divide is grammatically encoded and $s_{\text {arb }}$ does occur with lexical unaccusatives, an analysis à la Dobrovie-Sorin is not viable anymore.

Alternatively, Cinque 1988 argues that the properties of $s_{\text {arb }}$ constructions follow from a parametric choice regarding the argument status of $s_{\text {arb }}$ : certain languages have only a [ $\left.+\arg \right] s_{\text {arb }}$ that requires "association with a $\theta$-role at every level of representation", while other languages, in addition to the [+arg] $s_{\text {arb}}$, feature a $[-\arg ] s_{\text {arb }}$ which "serves as a syntactic mean to supplement personal Agr with the features able to "identify" [...] the content of pro as an unspecified (generic) person pronominal". In a nutshell, the $[+\arg ] s_{\text {arb }}$ is allowed only in combination with transitive and unergative verbs that project an EA (in that case, the subject position is filled by a null expletive

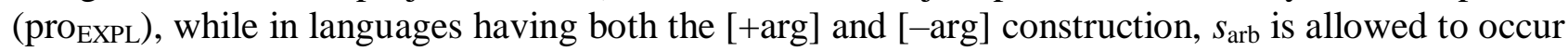
in any tensed environment in combination with a null subject ( pro $_{\mathrm{REF}}$ ), which, once combined with $s_{\text {arb}}$, is interpreted as a generic set of individuals:

$$
\begin{array}{lll}
\text { a. pro } \text { EXPL }_{\text {arb }}[+\arg ] & \rightarrow \text { allowed only with verbs projecting an EA } \\
\text { b. pro } & s_{\text {REF }}[-\arg ] & \rightarrow \text { allowed with any (tensed) verb }
\end{array}
$$

Cinque's hypothesis is supported by evidence from non-finite contexts, where only [+arg] $s_{\text {arb }}$ is expected to occur. In fact, $s_{\text {arb }}$ never occurs with non-finite unaccusatives, even in languages like Italian (see section 2.4).

The same analysis can account for case patterns. As the [+arg] $s_{\text {arb }}$ is not a fully-fledged argument, but rather a functional element absorbing the $\theta$-role, it blocks the assignment of Accusative case to the IA (in compliance with Burzio's generalization). Hence, in languages featuring only the $[+\arg ] s_{\text {arb}}$, the IA must be Nominative and, as a consequence, it cannot be pronominalized by an accusative clitic, cf. (8). Conversely, in languages allowing [-arg] $s_{\text {arb }}$ the 
external $\theta$-role is assigned to pro ${ }_{\mathrm{REF}}$, while Accusative is given to the IA, which can be therefore pronominalized by a complement clitic.

It is worth noting that the parametric choices [+arg] and [-arg] are not mutually exclusive. Despite the usage of \pm symbols (which may be misleading), [-arg] stands in an implicational relation to [+arg] as languages featuring [-arg] $s_{\text {arb }}$ do necessarily allow [+arg] $s_{\text {arb }}$, but not vice versa (for a possible counterexample, see Pescarini forth). This state of affairs can be captured by a hierarchical representation such as (19), in which three parametric options are envisaged: languages without $s_{\text {arb }}$ (like certain southern Italian dialects), languages that do not allow $s_{\text {arb }}$ with unaccusatives (e.g. old Italian); languages in which $s_{\text {arb }}$ can occur freely in tensed sentences and with object clitics (e.g. Italian).

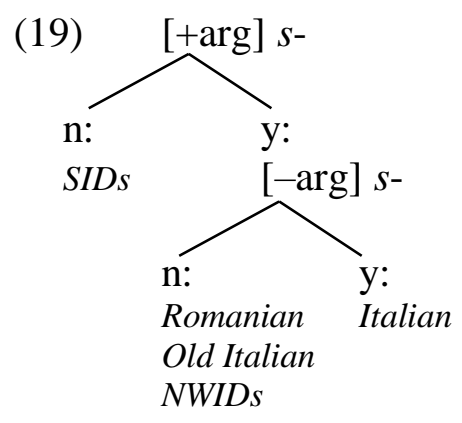

On the basis of (19), however, we expect $s_{\text {arb }}$ to be ungrammatical with all unaccusative predicates, while we have seen in the previous section that in some languages such as NWIDs (and, arguably, in Romanian) unaccusative verbs can combine with $s_{\text {arb }}$, while passives and copular constructions cannot. This must lead to a reformulation of the model in (19) in order to capture the distinction between old Italian, in which $s_{\text {arb }}$ never combines with unaccusatives, and Romanian/NWIDs, in which the restriction holds for passive and copular sentences.

Roberts 2010 proposes a reformulation of Cinque's dichotomy capitalizing on D'Alessandro 2007. He claims that $s_{\text {arb }}$ is first merged at the edge of v/v*min and bears a $\theta$-role. ${ }^{6}$ Then, Cinque's dichotomy is translated as follows:
(20) Cinque 1988
[+arg] $s_{\text {arb }}$
$[-\arg ] s_{\text {arb }}$

Roberts 2010

$s$ - values $v^{*}$ 's $\varphi$-features
$s$ - values T's $\varphi$-features

If $s_{\text {arb }}$ is merged in $\mathrm{v}^{*}$, it bears the external $\theta$-role and values $\mathrm{v}^{*}$ 's $\varphi$-features. With transitives, $s_{\text {arb }}$ prevents $\mathrm{v}^{*}$ from Case-license the IA, which eventually values $\mathrm{T}$, yielding the so-called passive-like construction.

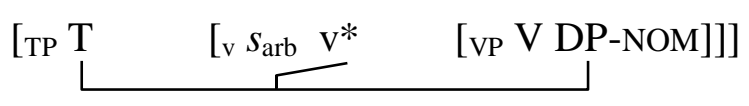

If $s_{\text {arb }}$ is merged in $\mathrm{v}$, it bears internal $\theta$-role and values T's $\varphi$-features, meaning that $s_{\text {arb }}$ can appear with unaccusative verbs, but only in tensed clauses where "T has a full $\varphi$-set" (Roberts 2010 : 123):

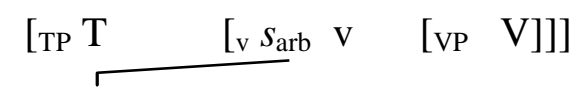

\footnotetext{
${ }^{6}$ In what follows, I assume that transitive and unergative verbs feature a $\mathrm{v}^{*}$ head introducing the EA and Case-licensing the IA (if present). Unaccusatives, conversely, feature a $v$ head.
} 
Furthermore, Roberts's analysis predicts a third agree configuration, occurring in transitive sentences when $s_{\text {arb }}$ values T, while the IA values $\mathrm{v}^{*}$, see (23). This condition, subject to parametric variation, allows the presence of accusative (clitic) objects in languages like Italian.

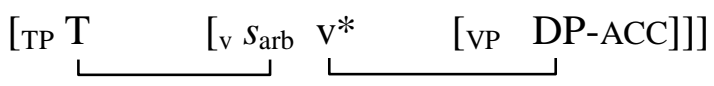

The three possible patterns resulting from Roberts's approach are summarised below:

(24) Parametric hierarchy on the distribution of $s_{\text {arb }}$ (to be refined)
a. $\left[\mathrm{v} s_{\text {arb }} \mathrm{V}^{*}\right]$
b. T $\left[\mathrm{v} S_{\text {arb }} \mathrm{v}\right]$ \}old Italian \} Romanian/NWIDs $\}$ Italian
c. $\mathrm{T}\left[\mathrm{v} S_{\text {arb }} \mathrm{V}^{*}\right]$

Notice that (24)c does not exclude (24)a: both are in fact allowed, giving rise to the alternation between the passive-like and the impersonal stricto sensu construction illustrated in (1) vs (2).

Hierarchies like (24) are expected to predict/account for the direction of linguistic change and the order of acquisition. I am assuming here a constraint-based model of acquisition in which each parametric option acts as a filter (see Calabrese 1995, 2005 on phonology). The set of parameters is ultimately viewed as a markedness system constraining linguistic acquisition and change. In origin, all filters are active (meaning that all the corresponding configuration are judged illicit) and are successively deactivated on the basis of Primary Linguistic Data. If no $s_{\text {arb }}$ construction occurs in the PLD, then the baby will acquire no arbitrary construction. Conversely, if a given filter is deactivated, then all lower-ranked parametric options will become grammatical. For instance, if PLD contain instances of $s_{\text {arb }}$ in passive clauses (as in modern Italian), then all filters will be deactivated; conversely, if PLD lack cases of $s_{\text {arb }}$ in unaccusative environments, then only the lowest filter will be activated, as in early Italian.

Although the ranking of above conditions may seem rather ad hoc, the hierarchy in (24) may follow from a general markedness principle such as (25):

(25) Agreement within a derived minimal head takes precedence over other agreement relations. ${ }^{7}$

Given (25), the most likely agreement configuration is the one in which $s_{\text {arb }}$ agrees with $\mathrm{v}^{*}$, cf. (24)a. By contrast, the most marked condition is the one in which $s_{\text {arb }}$ does not agree with $\mathrm{v}^{*}$, even if the latter is an active probe, cf. (24)c. (24)b is in between as $s_{\text {arb }}$ does not agree with $\mathrm{v}$, but in fact $\mathrm{v}$ is not an active probe.

In what follows I will capitalise on (24) in order to provide a better account of two main open issues: the various restrictions on the distribution of accusative clitics (section 4) and the restriction on passives (and copular constructions) holding in languages that allow $s_{\text {arb }}$ to occur with unaccusative verbs, e.g. NWIDs (section 5).

\section{Direct objects}

\footnotetext{
${ }^{7}$ Regarding the general topic of the direction of agreement, Roberts's theory entails that agreement within a derived minimal head is licit even if, strictly speaking, the probe does not c-command the goal (this is particularly true for $s_{\text {arb }}$, which, according to Roberts 2010: 120, is first-merged with $\mathrm{v}^{*}$ and it therefore never occurs in $\mathrm{v}^{*}$ 's c-command domain).
} 
Accusative clitics are sometimes banned in $s_{\text {arb }}$ constructions. In general, the restriction targets third person clitics, while first and second person clitics are free to occur with $s_{\text {arb: }}$ :
a. Finalmente me/te se vedde
At last me/you $=s=$ sees
'At last, one sees me'
b.*I se leza
them $=s=$ reads
'one reads them'

Analogously, in Spanish, first or second person clitics can freely combine with $s_{\text {arb }}$, see (27)a, while several restrictions, subject to a certain degree of crosslinguistic varation, target third person clitics: feminine pronouns (la, las) are allowed if the cliticised argument is marked by DOM, see (27)b; the latter condition holds for masculine objects as well, but in this case the accusative clitic lo/los is replaced by le/les even in dialects that do not exhibit leísmo, see (27)c (Mendikoetxea \& Battye 1990; Mendikoetxea 2008; Ordoñez and Treviño 2016):
a. Se me/te llama (Spanish)
$s=\mathrm{me} / \mathrm{you}=$ calls
'One calls me/you'
b. *(A) las niñas, se las ha visto contentas
To the girls $s=$ them.F= has seen happy
'one has seen the girls happy'
c. A los niños, se les/*los veía felices.
To the kids, $\quad s=$ to.them $=/ *$ them $=$ saw happy
'one saw them (the kids) happy'

The above data will be accounted for in the following three subsections, after a brief digression on the agreement pattern of $s_{\text {arb }}$ constructions (section 4.1): section 4.2 focuses on the asymmetry between first/second person and third person clitics, while section 4.3 deals with objects with DOM.

\subsection{Agreement restrictions}

The agreement pattern of $s_{\text {arb }}$ constructions is peculiar under two main respects. First, the IA cannot occur in the passive-like construction when first or second person, cf. (28)a vs (28)b.

(28) a. Lui si $\quad$ vede spesso in televisione
b. ${ }^{* T u}$ si
he/*you $s=$
'One see ofi spesso in televisione
'Onten see him/*you on TV'

Second, with unaccusative verbs, the past participle shows plural agreement ${ }^{8}$, while tensed forms always exhibit singular agreement, see (29). If we assume, on the basis of (29)a, that $s_{\text {arb }}$ has a [plural] specification, then one may conclude, on the basis of (29)b, that $s_{\text {arb }}$ never agrees with T. This, however, would annihilate Cinque's/Roberts's account of the ungrammaticality of $s_{\text {arb }}$ with unaccusative verbs (and accusative clitics): if no agree relation occurred between $s_{\text {arb }}$ and T, no asymmetry between tensed and untensed environments would be expected, contra (30).

(29) a. si parte/*partono

\footnotetext{
${ }^{8}$ On past participle agreement in Romance and, in particular, in $s_{\text {arb }}$ constructions, see Loporcaro 1998, Bentley 2006.
} 
$\mathrm{s}=$ leave-SG/*PL

'we leave'

b. si è/*sono partit-i

$\mathrm{s}=$ is/*are left-PL

'we have left'
a. Poiché si è arrivati tardi, siamo
ripartiti subito
(tensed; Italian)
Since $s=$ is arrived late, we.are left immediately.
'As we had arrived late, we left immediately'
b. Essendo-si arrivati tardi, siamo ripartiti subito.
(untensed)
Being $=s$ arrived late, we.are left immediately.
'As we had arrived late, we left immediately'

To account for the agreement mismatch illustrated in (29), I follow Bianchi (2006: 226ff) and D'Alessandro (2007: 28-31, 200-201) in claiming that $s_{\text {arb }}$ does not bear any Number specification and that the past participle in a case like (29)b, as well as predicative adjectives, exhibits semantic agreement. Whereas grammatical agreement is a feature sharing operation in which the features of a probing element (the target of agreement) are valued by matching with the features of a goal (the controller of agreement), semantic agreement arises when the features of the probe/target are valued on the basis of semantic information (derived from contextually salient or encyclopaedic information; Corbett 2006:155-157), possibly introduced in the syntactic spine by means of logophoric operators (see Sigurðsson 2004 a.o.).

The hypothesis that participles show semantic agreement more readily than inflected verbs is supported by another agreement mismatch, which can be observed with courtesy forms: in Italian, when an honorific second person plural form is used to refer to the addressee, the past participle is singular (even if the courtesy form is an object clitic as in (31)b; recall that, in Italian, object clitics always agree in gender and number with the participle), while the auxiliary exhibits syntactic plural agreement in both examples:

(31) a. Voi siete partit-o senza dircelo

You.pl are.pl left.sg without letting us know

'You left without letting us know'
b. Vi ho vist-o
You=I.have seen.sg
'I have seen you'

However, even assuming that the inflection of the past participle in (29) and (31) results from semantic rather than syntactic agreement, then why does not the auxiliary in (29) agree? Bianchi convincingly argues that the auxiliary cannot exhibit semantic plural agreement as Number agreement is parasitic on Person agreement and $s_{\text {arb }}$ fails to trigger Person agreement because of its arb specification, i.e. its Person feature is [Person: $a r b$ ]. The featural content of $s_{\text {arb }}$ is therefore as follow ${ }^{9}$ : the Person feature has an arb specification, while the Number feature is unspecified.

$$
\mathrm{T}[\mathrm{uPers} ; \mathrm{uNum}] \ldots\left[\mathrm{v}\left[{ }_{s i} \text { iPers: } a r b ; \text { iNum: __ }\right] \mathrm{v}\right]
$$

The analysis in (32) departs slightly from D'Alessandro's (D'Alessandro 2007: 33), which assumes that $s_{\text {arb }}$ has a third person feature, i.e. [Pers: 3]. The latter proposal aims to account for the

\footnotetext{
${ }^{9}$ I adopt the following conventions:

- $\quad i F / u F$ for interpretable/uninterpretable Features

- $\quad F: x / F:_{-}$for valued/unvalued Features
} 
aforementioned restriction on first and second person IAs in passive-like constructions (D’Alessandro 2007: 91-131):

$\begin{array}{llll}* \text { Voi } & \text { si/vi } & \text { vedete } & \text { in televisione } \\ \text { you.PL }= & s i= & \text { see.2PL } & \text { on TV }\end{array}$

'One can see you on TV'

D'Alessandro argues that the ungrammaticality of (33) is due to a condition on multiple agree (Anagnostopoulou 2003) disallowing the occurrence of IAs whose Person feature - [Pers: 1/2] differs from the one of $s_{\text {arb }}$ ([Pers: 3]). However, the same analysis holds once it is assumed that third person is represented by means of an underspecified Person feature, i.e. [Person: ], as proposed above and, among many others, by D'Alessandro and Roberts (2010: 54 and fn. 8).

The analysis of (33) is as follows: $s_{\text {arb}}$, which has the features [iPers: $a r b$; iNum: _], is merged in $\mathrm{V}^{*}$ and values $\mathrm{v}^{*}$ 's features (à la Roberts 2010) ${ }^{10}$. Then $\mathrm{T}$ probes both $s_{\text {arb }}$ and the IA: the sentence is ungrammatical if the IA has a Person specification (i.e. [Person: 1/2]) that conflicts with the one of $s_{\text {arb}}$, namely [Pers: $a r b$ ]. Conversely, the sentence is grammatical if the IA is third person because its Person feature is underspecified, i.e. [Pers: __ ]. In the latter case, a multiple agree configuration can take place as the $\varphi$-features of $s_{\text {arb }}$ and the IA are compatible.

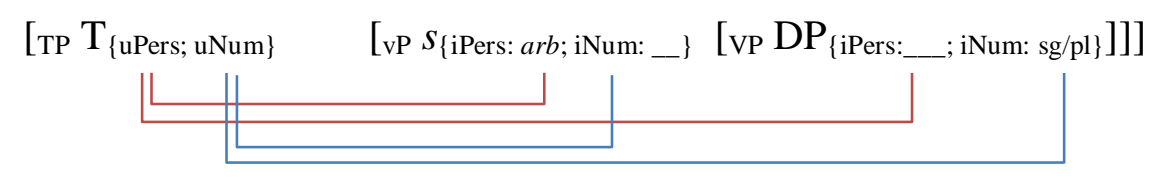

In the light of (34), Roberts's 2010 analysis can be refined. In fact, (34) shows that $s_{\text {arb }}$ always values $\mathrm{T}$, while the parametric distinctions we are dealing with depend on whether $s_{\text {arb }}$ must/can/cannot value $\mathrm{v} / \mathrm{v}^{*}$.

\subsection{First and second person clitics}

The multiple agree hypothesis introduced in the preceding section can shed light on the behaviour of first and second person accusative clitics. Recall that third person accusative clitics are often banned in $s_{\text {arb }}$ constructions, while first and second person clitics are free to occur with the impersonal $s_{\text {arb: }}$ :

$$
\begin{aligned}
& \text { a. Finalmente me/te se vedde } \\
& \text { At last me/you= s= sees } \\
& \text { 'At last, one sees me' } \\
& \text { b. }{ }^{*} \quad \text { se leza } \\
& \text { them }=\quad s=\text { reads } \\
& \text { 'one reads them' }
\end{aligned}
$$

(Genovese)

Intuitively, the asymmetry in (35) correlates with the agreement restriction illustrated in the preceding section. Recall that third person IAs can freely occur in the passive-like construction, while first or second person IAs cannot because their Person specification conflicts with the one of

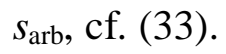

\footnotetext{
${ }^{10}$ It is worth noting that $s$ - is not an intervener preventing T from probing the IA (Roberts 2010). However, following D'Alessandro 2007, this does not exclude that $s_{\text {arb }}$ plays a role in the valuation of $\mathrm{T}$, which is eventually valued combining the (matching) features of the two goals.
} 
Hence, first and second person IAs are always excluded from arbitrary constructions in languages allowing only the passive-like construction, i.e. unless the configuration in $(24) \mathrm{c} /(36) \mathrm{c}$ is permitted. This, in my opinion, is the reason why certain languages such as Genovese in (35) tend to be more liberal with first and second person IAs and eventually allow the most marked option of the hierarchy when the IA is first or second person.

(36) Parametric hierarchy on the distribution of $s_{\text {arb }}$ (to be refined)
a. $\left[\mathrm{v} s_{\text {arb }} \mathrm{V}^{*}\right]$ \}old Italian
b. T $\left[{ }_{\mathrm{v}} S_{\text {arb }} \mathrm{v}\right]$ Romanian/NWIDs Ligurian (iff IA is $1 / 2 \mathrm{p}$ ) Spanish (iff IA is $1 / 2 \mathrm{p}$ )
c. T $\left[\mathrm{v} S_{\text {arb }} \mathrm{V}^{*}\right]$ Italian

With third person IAs, conversely, (24)/(36)a does not yield any agreement violation. As a consequence, there is no need to allow the most marked option of the hierarchy when the IA is third person.

\subsection{Applied objects}

Besides first or second person clitics, Spanish allow third person clitics to occur in a $s_{\text {arb }}$ construction if the cliticised argument is marked by DOM, see (37) (Mendikoetxea 2008; Ordoñez and Treviño 2016):
a. *(A) las niñas, se las ha visto contentas To the girls $s=$ them.F= has seen happy 'one has seen the girls happy'

b. A los niños, les/*los veía felices. To the kids, to.them=/*them= saw happy 'I saw them (the kids) happy'

Ordoñez and Treviño 2016 argue that DOM objects are licensed by an applicative head, see (38). This amounts to saying that sentences featuring DOM do not have the structure of plain transitive clauses as $\mathrm{v}^{*}$ does not Case-license the IA anymore.

$$
\left[\mathrm{vP}^{*}\left[\mathrm{ApplP} \text { IA }\left[\mathrm{Appl}^{0} \mathrm{VP}\right]\right]\right]
$$

This yields the contrast between applied objects, which can co-occur with $s_{\text {arb}}$, and plain objects, which cannot:
a. $\left[{ }_{\mathrm{vP}} S_{\mathrm{arb}} \mathrm{V}^{*}\left[\mathrm{ApplP} \mathrm{IA}\left[\mathrm{Appl}^{0} \mathrm{VP}\right]\right]\right]$
$s_{\text {arb }}+$ applied object
b. $*\left[{ }_{\mathrm{vP}} S_{\mathrm{arb}} \mathrm{V}^{*}[\mathrm{vP} \mathrm{V}\right.$ IA] $]$
$s_{\text {arb }}+$ plain object

Given (39), we can capture the behaviour of Spanish-type languages by assuming a further condition stating that in languages like Spanish $s_{\text {arb }}$ can be merged in a transitive $\mathrm{v}^{*}$ if and only if $\mathrm{v}^{*}$ does not Case-license the IA.

(40) $s_{\text {arb }}$ does not value $\mathrm{v}^{*}$ iff $\mathrm{v}^{*}$ does not Case-check

$\left(\rightarrow s_{\text {arb }}\right.$ is allowed in combination with applied objects, not plain objects) 
This extra condition can be eventually added to the parametric hierarchy introduced so far, which reads as follows:

(41) Parametric hierarchy on the distribution of $s_{\text {arb: }}$ :
a. $\left[\mathrm{v} s_{\text {arb }} \mathrm{V}^{*}\right]$
b. $\mathrm{T}\left[\mathrm{v} S_{\text {arb }} \mathrm{V}\right]$ \}old Italian $\left.\begin{array}{l}\text { Romanian/NWIDs } \\ \text { Case-check }\end{array}\right\}$ Spanish \} Italian
d. T [v $\left.S_{\text {arb }} \mathrm{V}^{*}\right]$

The above condition will be discussed in greater detail in the following section.

\section{Passives and copular constructions}

As previously mentioned, in several, but not all, Romance languages, $s_{\text {arb }}$ can occur in passive clauses. When this happens, $s_{\text {arb }}$ must bear internal $\theta$-role and, consequently, cannot co-occur with an IA:
a. Si è stati visti
(Italian)
$s=$ is been seen
'we have been seen'
b. $*$ Si è stata mangiata la mela
$s=$ is been eaten the apple
'The apple has been eaten'

To account for the argument structure in (42) and the ungrammaticality of $s_{\text {arb }}$ passives in certain languages, I depart from analyses in which passives are derived by merging $\mathrm{V}$ with a defective $\mathrm{V}$ and assume that passivization is due to a syntactic operation merging a transitive $\mathrm{v}^{*}$ with a Voice head (Collins 2005, reminiscent of Chomsky 1957). Then, Voice Case-license the EA, while the caseless IA is smuggled to T via spec VoiceP.

What is crucial in Collins's analysis is that, to merge with Voice, $\mathrm{v}^{*}$ must assign external $\theta$-role to its spec, although it cannot check Accusative anymore. In Collins's words: "Suppose X (v or P) has a Case-checking feature $[\mathrm{uF}]$, then it is possible for $[\mathrm{uF}]$ to be dissociated from $\mathrm{X}$, and for $[\mathrm{uF}]$ to be added to the numeration as part of the functional head VoiceP."

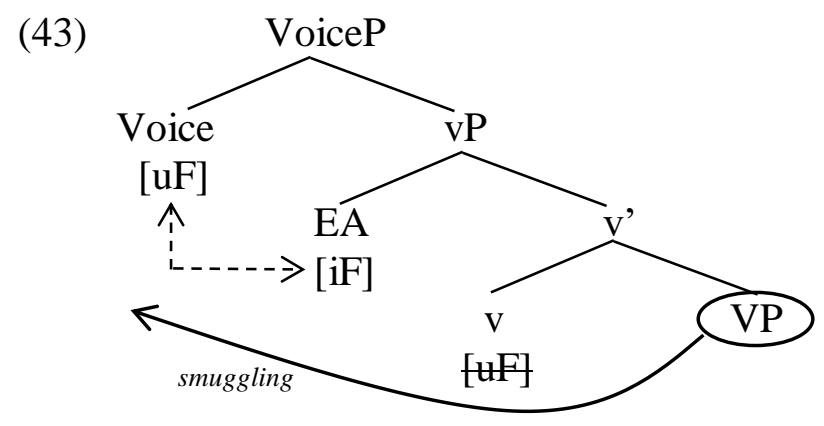


In this respect, passivized $\mathrm{v}^{*}$ differs from either unaccusative $\mathrm{v}$ or active $\mathrm{v}^{*}$, as summarised in the following table:

$\begin{array}{llll} & \mathrm{V} & \mathrm{V}^{*} \text { (passive) } & \mathrm{V}^{*} \text { (active) } \\ \text { assigns external } \theta \text {-role } & - & + & + \\ \text { bears a Case-feature } & - & - & +\end{array}$

In the light of the above analysis, the data in (42) follow straightforwardly from Roberts's analysis: if $s_{\text {arb }}$ bore external $\theta$-role, it would prevent $\mathrm{v}^{*}$ from projecting its spec and, consequently, from merging with Voice. In fact, to undergo passivisation, $\mathrm{v}^{*}$ must assign external $\theta$-role to its spec, which is eventually Case-licensed by Voice, see (43). For this reason, $s_{\text {arb }}$ can occur in passives if and only if it bears internal $\theta$-role, as in (42)a.

Furthermore, an analysis à la Collins may explain why in certain languages such as Romanian and NWIDs $s_{\text {arb }}$ can occur with unaccusative verbs, but not with passives. If both had the same structure, the asymmetry would remain unaccounted for. Conversely, by assuming (43)-(44), one can argue that in Romanian and NWIDs $s_{\text {arb }}$ can be merged with unaccusative v, but cannot occur in structures featuring a passive $\mathrm{v}^{*}$.

In particular, my hypothesis is that the restriction observed in Romanian-like languages follows from the same condition introduced in the previous section and repeated in (45). Recall that, in the case of passives, $\mathrm{v}^{*}$ ' $\mathrm{s}$ Case feature is "added to the numeration as part of the functional head VoiceP" (Collins 2005).

(45) Parametric hierarchy on the distribution of $s_{\mathrm{arb}}$ :

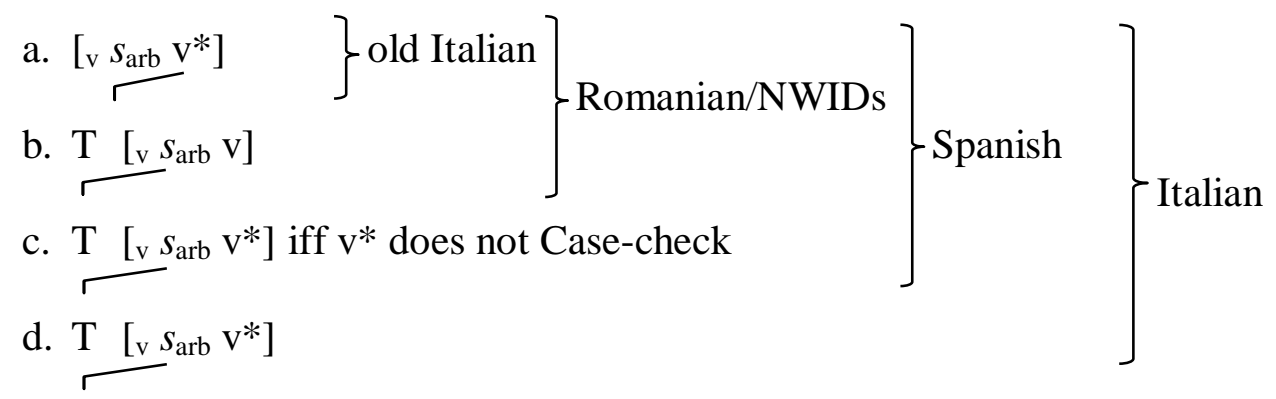

Thus, in languages in which (45)c is an active parametric choice, $s_{\text {arb }}$ can be merged with passive $\mathrm{V}^{*}$ and with DOM objects (as in Spanish). Conversely, in languages in which (45)c does not hold (recall the hierarchy in (41)), $s_{\text {arb }}$ is ungrammatical in either passives or with DOM objects. The prediction is borne out: in fact, besides Passives, Romanian does not allow $s_{\text {arb }}$ to co-occur with DOM objects as well (Dobrovie-Sorin 1998: 405):
a. En esta escuela se castiga a los alumnos. in this school $s=$ punishes DOM students
'In this school they punish the students.'
b. *In şcoala asta se pedepsesţe pe elevi. in school this $s=$ punishes DOM students 'In this school they punish the students.'
(Spanish)
(Romanian)

Furthermore, I argue that the condition in (45)c accounts for the (un)grammaticality of $s_{\text {arb }}$ in predicative constructions such as (47). I claim that the copula is a peculiar $\mathrm{v}^{*}$ head that, despite assigning external $\theta$-role, does not normally license accusative arguments (but see Lohndal 2006 on the distinction between nominative-nominative and nominative-accusative copula constructions in Norwegian). In fact, the copula never takes as its complement a fully-fledged argument, but only an 
AP or a Predicative Determiner Phrase (PDP; Zamparelli 2000), i.e. a property-denoting element that does not require Case-licensing, see (48):

a. Non si è mai soddisfatti

(Italian)

Not $s=$ is never satisfied

'One is never satisfied.'

b. Si è un vero scrittore quando si è scritto un libro $s=$ is a true writer when $s=$ is written a book 'You are a true writer after having written a book'

$\left[\mathrm{DP}\left[\mathrm{v}^{*} \mathrm{AP} / \mathrm{PDP}\right]\right]$

Evidence for (48) comes from agreement as in the languages under scrutiny $\mathrm{T}$ is always valued by the (only) DP argument, while PDPs cannot control agreement even in inverse constructions such as (49)b:
a. Le guerre sono la causa delle migrazioni
The wars are the cause of.themigrations
'Wars are the cause of migrations'
b. la causa delle migrazioni *è/sono le guerre
The cause of.the migrations is/are the wars
The cause of migrations is wars

To summarise, in this section I have argued that passive and predicative constructions do not feature a defective $\mathrm{v}$, but a $\mathrm{v}^{*}$ head that, although assigning external $\theta$-role, does not Case-license. In this respect, these constructions depart from either unaccusative structures, where no external $\theta$ role is assigned, or transitive/unergative structures, where the internal argument (if any) can be Case-licensed by agreeing with $v^{*}$.

\section{Conclusion}

This article has addressed a series of restrictions on the distribution of $s_{\text {arb}}$, which is summarised in the following table:

\begin{tabular}{|l|c|c|c|c|}
\cline { 2 - 5 } \multicolumn{1}{c|}{} & old It. & Ro.; NWIDs & Sp. & It. \\
\hline Unaccusative verbs & $\mathbf{x}$ & $\checkmark$ & $\checkmark$ & $\checkmark$ \\
\hline Passive and copular constructions & $\mathbf{x}$ & $\mathbf{x}$ & $\checkmark$ & $\checkmark$ \\
\hline Co-occurrence with 3p clitics & $\mathbf{x}$ & $\mathbf{x}$ & $\%$ & $\checkmark$ \\
\hline
\end{tabular}

Occurrence of $s_{\text {arb }}$ in old Italian, Romanian, North Western Italian dialects, Spanish, and Italian in tensed clauses

Building on Roberts 2010, I argued that the above cross-linguistic distribution results from the parametric hierarchy in (51) (recall that lower options entail higher ones). All languages with impersonal $s_{\text {arb }}$ constructions allow (51)a: $s_{\text {arb }}$ occur with unergative and transitive verbs bearing external $\theta$ role; with transitives, since $s_{\text {arb }}$ values $\mathrm{v}^{*}$, the IA must value $\mathrm{T}$ yielding the so called passive-like construction. Besides (51)a, languages such as Romanian and northwestern Italian dialects allow the configurations in (51)b: $s_{\text {arb }}$ is allowed with unaccusatives, but cannot occur in passives and with accusative objects as, with $\mathrm{v}^{*}$, the only possible agreement pattern remains (51)a. Languages like Spanish allow (51)a-c, thus exhibiting $s_{\text {arb }}$ with passives and DOM objects. Lastly, languages such as Italian allow all the parametric options in (51)a-d, meaning that $s_{\text {arb }}$ can occur in 
all tensed environments, including accusative clauses featuring fully fledged accusative objects (clitic or not).

(51) Parametric hierarchy on the distribution of $s_{\text {arb: }}$ :
a. $\left[{ }_{\mathrm{v}} s_{\text {arb }} \mathrm{V}^{*}\right]$

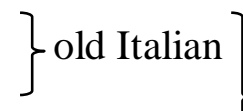
b. $\mathrm{T}\left[\mathrm{v} S_{\text {arb }} \mathrm{v}\right]$
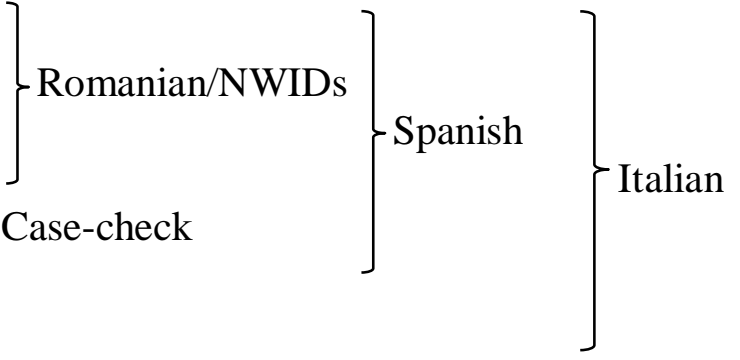
c. $\mathrm{T}\left[\mathrm{v} s_{\text {arb }} \mathrm{V}^{*}\right]$ iff $\mathrm{v}^{*}$ does not Case-check
d. T $\left[\mathrm{v} S_{\text {arb }} \mathrm{V}^{*}\right]$

As previously mentioned, the ranking between the above conditions follows from a general principle such as (52):

(52) Agreement within a derived minimal head takes precedence over other agreement relations. ${ }^{11}$

Given (52), the most likely agreement configuration is the one in which $s_{\text {arb }}$ agrees with $\mathrm{v}^{*}$, cf. (51)a, while the most marked condition is the one in which $s_{\text {arb }}$ does not agree with $\mathrm{v}^{*}$, cf. (51)d. (51)b and (51)c are in between as in both $\mathrm{v} / \mathrm{v}^{*}$ cannot Case-license as it does not bear a full set of features.

\section{References}

Bentley, D. (2006). Split Intransitivity in Italian. Berlin: De Gruyter.

Brandi, Luciana and Patrizia Cordin. 1989. Two Italian Dialects and the Null Subject Parameter. In: Jaeggli, Osvaldo and Ken Safir (eds). The null subject parameter. Dordrecht: Kluwer.

Burzio, L. (1986). Italian Syntax. Dordrecht: Foris.

Calabrese, Andrea 1995. 'A constraint-based theory of phonological markedness and simplification procedures' Linguistic Inquiry 26.2: 373-463

Calabrese, Andrea 2005. Markedness and Economy in a Derivational Model of Phonology. New York - Berlin: De Gruyter.

Cardinaletti, A. (1997). 'Subjects and Clause Structure' in L. Haegeman (ed.), The New Comparative Syntax. London: Longman, pp. 33-63.

Cennamo M. (1993). The Reanalysis of Reflexives: a Diachronic Perspective, Napoli, Liguori.

Cennamo M. (1995). 'Transitivity and VS order in Italian reflexives' STUF 48: 84-105.

Cennamo M. (1997). 'Passive and impersonal constructions' in M. Parry, M. Maiden, The dialects of Italy, London, Routledge, pp. 145-61.

Chomsky, N. (1957). Syntactic Structures, The Hague: Mouton.

Cinque G. (1988). 'On si constructions and the theory of arb' Linguistic Inquiry 19, 521-82.

Collins, C. (2005). 'A smuggling approach to the passive in English' Syntax 8.2: 81-120. DOI: 10.1111/j.1467-9612.2005.00076.x.

Comrie, B. (1985). Tense. Cambridge: Cambridge University Press.

Corbett, G. (2006). Agreement. Cambridge: Cambridge University Press.

Cuervo, M. (2014). 'Alternating unaccusatives and distribution of roots' Lingua 141: 48-70.

\footnotetext{
${ }^{11}$ Regarding the general topic of the direction of agreement, Roberts's theory entails that agreement within a derived minimal head is licit even if, strictly speaking, the probe does not c-command the goal (this is particularly true for $s_{\text {arb}}$, which, according to Roberts 2010: 120, is first-merged with $\mathrm{v}^{*}$ and it therefore never occurs in $\mathrm{v}^{*}$ 's c-command domain).
} 
D’Alessandro, R. (2007). Impersonal si constructions. Berlin - New York: Mouton De Gruyter.

D'Alessandro, R. \& D. Pescarini (2016). 'Agreement Restrictions and agreement oddities in Romance', in S. Fischer and Ch. Gabriel (eds.), Manual of Grammatical Interfaces in Romance. Berlin - New York: De Gruyter.

D'Alessandro, R. \& I. Roberts (2008). 'Movement and agreement in Italian past participles and defective phases'. Linguistic Inquiry 39.3: 477-491. DOI: 10.1162/ling.2008.39.3.477

D'Alessandro, R. \& I. Roberts (2010). 'Past participle agreement in Abruzzese: split auxiliary selection and the null-subject parameter'. Natural Language and Linguistic Theory 28: 41-72. DOI: $10.1007 / \mathrm{s} 11049-009-9085-1$

Dobrovie-Sorin C. (1998). 'Impersonal se Constructions in Romance and the Passivization of Unergatives', in Linguistic Inquiry 29.3, 399-437. DOI: 10.1162/002438998553806

Dobrovie-Sorin C. (2006), 'The SE-anaphor and its role in argument realization', in M. Everaert, H. van Riemsdijk (eds.), The Blackwell Companion to Syntax, vol 4, Oxford, Blackwell. DOI: 10.1002/9780470996591.ch56

Kayne, R. (1986). Participles, Agreement, Auxiliaries, Se/Si and pro, New York University, ms.

Kayne, R. (1996). 'Microparametric syntax: some introductory remarks' in James R. Black \& V. Montapanyane (eds.), Microparametric syntax and dialect variation. Amsterdam: Benjamins, ixxvii. (Reprinted in Kayne 2000. Parameters and universals. New York: Oxford University Press, 3-9).

Lohndal, T. (2006). 'The phrase structure of the copula' Working Papers in Scandinavian Syntax 78: $37-75$

Loporcaro, M. (1998). Sintassi comparata dell'accordo participiale romanzo. Turin: Rosenberg \&. Sellier.

Manzini, M.R. (1986). 'On Italian si' in H. Borer (ed.), Syntax and Semantics XIX: The syntax of pronominal clitics. New York: Academic Press: 241-262.

Manzini, R. \& L. Savoia (1997). 'Null subjects without pro' UCL Working Papers in Linguistics 9: $1-12$.

Mendikoetxea, Amaya (2008). 'Clitic impersonal constructions in Romance: syntactic features and semantic interpretation' Transactions of the Philological Society 106.2: 290-336.

Mendikoetxea, Amaya \& Adrain Battye (1990). 'Arb se/si in transitive contexts: a comparative study' Rivista di grammatica generativa 15: 161-195.

Ordóñez F. \& E. Treviño (2016). 'Agreement and D.O.M. with se: A comparative study of Mexican and Peninsular Spanish' in Kato, Mary and Francisco Ordóñez (eds), The Morphosyntax of Portuguese and Spanish in Latin America, Oxford: Oxford University Press.

Parry M. (1995), Costruzioni impersonali in Piemontese, in At del XI Recontr internassional de studi an sla lenga e literatura Piemonteisa, Quinsne, 247-59.

Parry M. (1998). 'The Reinterpretation of the Reflexive in Piedmontese: 'Impersonal' SE Constructions', in Transactions of the Philological Society 96, pp. 63-116. DOI: 10.1111/1467968X.00024

Pescarini, Diego (forth.). 'Subject and impersonal clitics in northern Italian dialects' in R. Petrosino, P. Cerrone, H. van der Hulst Beyond the veil of Maya - from sounds to structures. Berlin, Mouton De Gruyter.

Roberts, Ian 2010. Agreement and Head Movement. Clitics, Incorporation, and Defective Goals. Cambridge (Mass.): MIT Press.

Roberts, I. \& Holmberg, A. 2010. 'Parameters in minimalist theory', in Biberauer et al. Parametric Variation. Cambridge: Cambridge University Press.

Saccon, G. (1993). Postverbal Subjects. Doctoral Dissertation, Harvard University.

Salvi, G. (2008a). La formazione della costruzione impersonale in italiano, in "Revista de Estudos Linguísticos da Universidade do Porto" 3, pp. 13-37. 
Salvi, G (2008b). "Imperfect systems and diachronic change". In The Paradox of Grammatical Change: Perspectives from Romance, ed. by Detges, Ulrich and Richard Waltereit. Amsterdam: Benjamins: 127-146. DOI: 10.1075/cilt.293.07sal

Salvi, G. (2010). 'La realizzazione sintattica della struttura argomentale' in G. Salvi \& L. Renzi (eds.), Grammatica dell'Italiano antico. Bologna: Il Mulino, 123-190.

Sansò. A. \& A. Giacalone Ramat (2016). 'Deictic motion verbs as passive auxiliaries: the case of italian andare 'go' (and venire 'come')'. Transactions of the Philological Society 114: 1-24.

Sheehan, M. (2006). The EPP and null subjects in Romance. Newcastle University: PhD dissertation.

Sigurðsson, H. Á. (2004). 'The syntax of Person, Tense, and speech features' Italian Journal of Linguistics 16:219-251.

Zamparelli, R. (2000). Layers in the Determiner Phrase. New York: Garland. 